\title{
Population Size and Natural History of Mariana Fruit Bats (Chiroptera: Pteropodidae) on Sarigan, Mariana Islands ${ }^{1}$
}

\author{
Gary 7. Wiles ${ }^{2,3}$ and Natban C. Fobnson ${ }^{4}$
}

\begin{abstract}
Based on count results, we estimated the population of Mariana fruit bats (Pteropus mariannus Desmarest) on Sarigan, Mariana Islands, to number $150-200$ bats in $1999,185-235$ bats in 2000 , and about $300-400$ bats in 2001 . Our results, plus those of two previous surveys, indicate that bat abundance on the island probably remained relatively stable at about 125-235 animals during much of the period from 1983 to 2000 , then increased suddenly in 2001, most likely due to immigration from a neighboring island. Sarigan's population differs from those of larger islands in the archipelago by usually having smaller roost sizes, typically 3-75 bats, and large numbers of solitary bats that at times comprise up to half of the population. Colonies and smaller aggregations were composed primarily of harems with multiple females, whereas a nearly equal sex ratio occurred among solitary animals. Colonies roosted in isolated coconut trees in open grasslands and in native forest stands of various sizes, but avoided dense coconut forest. An estimated $30-50 \%$ of harem and solitary females possessed young in July 1999. Bats were recorded feeding on just six species of plants, which partly reflects the island's impoverished flora. We speculate that fruit bat abundance on Sarigan is limited primarily by food availability rather than hunting losses, in contrast to some other islands in the Marianas. Our study supports the contention that populations of $P$. mariannus in the northern Marianas are usually sedentary, but that interisland movements of larger numbers of bats may occur rarely.
\end{abstract}

The Mariana fRuit bat (Pteropus mariannus Desmarest) ranges over nearly the entire length of the Mariana Islands in western Micronesia and is presumed to have once

${ }^{1}$ Funding was provided by the U.S. Navy and the U.S. Fish and Wildlife Service Federal Aid to Wildlife Restoration Projects for the Commonwealth of the Northern Mariana Islands (Project W-1-R-1) and Guam (Project W-1R-7). Manuscript accepted 17 November 2003.

${ }^{2}$ Division of Aquatic and Wildlife Resources, 192 Dairy Road, Mangilao, Guam 96913.

${ }^{3}$ Current address: 521 Rogers Street SW, Olympia, Washington 98502 (phone: 360-943-8786; e-mail: wilesharkey@yahoo.com).

${ }^{4}$ USGS Forest and Rangeland Ecosystem Science Center, 3200 SW Jefferson Way, Corvallis, Oregon 97331 (e-mail: Njohnson@usgs.gov).

Pacific Science (2004), vol. 58, no. 4:585-596 (C) 2004 by University of Hawai $i$ Press

All rights reserved been abundant throughout the archipelago. During the past century, fruit bat populations on the main southern islands of Guam, Rota, Tinian, and Saipan have seriously declined due to overhunting, forest loss, and, on Guam, predation by introduced brown tree snakes, Boiga irregularis (Bechstein) (Wheeler 1980, Wiles 1987, Wiles et al. 1989, 1995, Stinson et al. 1992, Krueger and O'Daniel 1999). In the northern volcanic portion of the island chain, fruit bat populations have been considered more secure because of their isolation from humans. A survey in 1983 estimated that a minimum of about 7,500 bats remained on eight northern islands, representing $82-85 \%$ of the total bats present in the archipelago (Wiles et al. 1989). However, subsequent surveys have detected noticeable decreases in bat abundance on two of the islands of key conservation importance, Anatahan and Pagan (Johnson 2001, Worthington et al. 2001), where the species was most common in 1983, suggesting that northern 
island bat populations are indeed vulnerable to decline. Chronic illegal hunting and forest degradation caused by feral ungulates are considered the primary threats to $P$. mariannus on those islands (Wiles et al. 1989, Johnson 2001, Worthington et al. 2001).

The difficult access and terrain that have served to protect fruit bats on the volcanic northern Mariana Islands have also discouraged scientific studies of those populations. Hence, little information is available on the status and biology of bats inhabiting those islands. The northern islands are considerably smaller than their southern counterparts and have less diverse forests; thus the natural history of their bats may differ from that observed in the southern Marianas. In this paper, we report the results of population surveys conducted annually on the island of Sarigan from 1999 to 2001. Data on roosting behavior, reproduction, and diet are also provided and compared with information for populations elsewhere in the species' range.

\section{Study Area}

Sarigan $\left(16^{\circ} 42^{\prime} \mathrm{N}, 145^{\circ} 47^{\prime} \mathrm{E}\right)$ measures 5.0 $\mathrm{km}^{2}$ in size and is characterized throughout by steep topography (Figure 1). A dormant cone located in the south-central portion of the island dominates the landscape and reaches an elevation of $538 \mathrm{~m}$. Sarigan's terrain is most rugged in the south, where extensive broken slopes fall sharply to the ocean and many ravines are present, but is less severe and more easily traversed in the north. The climate is tropical, with daily temperatures of $24-32^{\circ} \mathrm{C}$, high humidity, and average annual rainfall of $200-260 \mathrm{~cm}$.

Forest covers about $32 \%$ of the island, or about 162 ha, but is restricted primarily to the northwestern corner. Much of this area was converted into a coconut (Cocos nucifera L.) plantation in the early 1900s (Farrell 1991). Coconut forest (133 ha) remains the dominant forest type, although some native trees are intermixed. Stands of native forest (29 ha) are also present, with Aglaia mariannensis Merrill, Hibiscus tiliaceus L., C. nucifera, Erytbrina variegata L., Neisosperma oppositifolia (Lam.) Fosb. \& Sachet, Carica papaya L., Ficus prolixa Forst. f., Pisonia grandis R. Brown, and F. tinctoria (Summerh.) Fosb. being the most common trees (Ohba 1994, de Cruz et al. 2000). Canopy height is $8-15 \mathrm{~m}$ tall. Small scattered pockets of forest occur in protected ravines elsewhere on the island. Grasslands, open fern cover, and bare ground are other major habitats. Cbrysopogon aciculatus (Retz.) Trin. and swordgrass (Miscantbus floridulus (Labill.) Warb. ex K. Schum. \& Laut.) are the major grass species (Ohba 1994), and Pteris quadriaurita Retz. s.l. and Nepbrolepis birsutula (Forst. f.) Presl are the most common ferns. Isolated coconut trees are present in some grassy areas, especially along the northeastern coast.

Sarigan is under the administration of the Commonwealth of the Northern Mariana Islands (CNMI). Although the island has been uninhabited since about 1970 , it continued to be visited occasionally by people during the 1990s, primarily for hunting. It held a large population of about 900 feral goats (Capra bircus L.) and 70 feral pigs (Sus scrofa L.) until 1998-1999, when an eradication campaign successfully eliminated both species (Zoology Unlimited LLC 1998). These animals severely damaged the island's vegetation, although some recovery was apparent during our study (de Cruz et al. 2000). The sprawling vine Operculina ventricosa (Bert.) Peter is one plant that has become much more abundant since 1998.

\section{MATERIALS AND METHODS}

We conducted fruit bat surveys during three trips to Sarigan from 2 to 7 July 1999, 2 to 8 July 2000, and 14 to 15 July 2001. The first two visits were part of broader inventories of the island's wildlife and vegetation, with one person devoted mainly to bat work each trip. However, other trip participants assisted with station counts and provided opportunistic observations, especially on the locations of bat colonies. In contrast to these groundbased efforts, the 2001 survey was made primarily by helicopter, in which a single spotter assisted by the pilot attempted to sight colonies. Only a small amount of time was spent on the ground censusing one bat roost. 


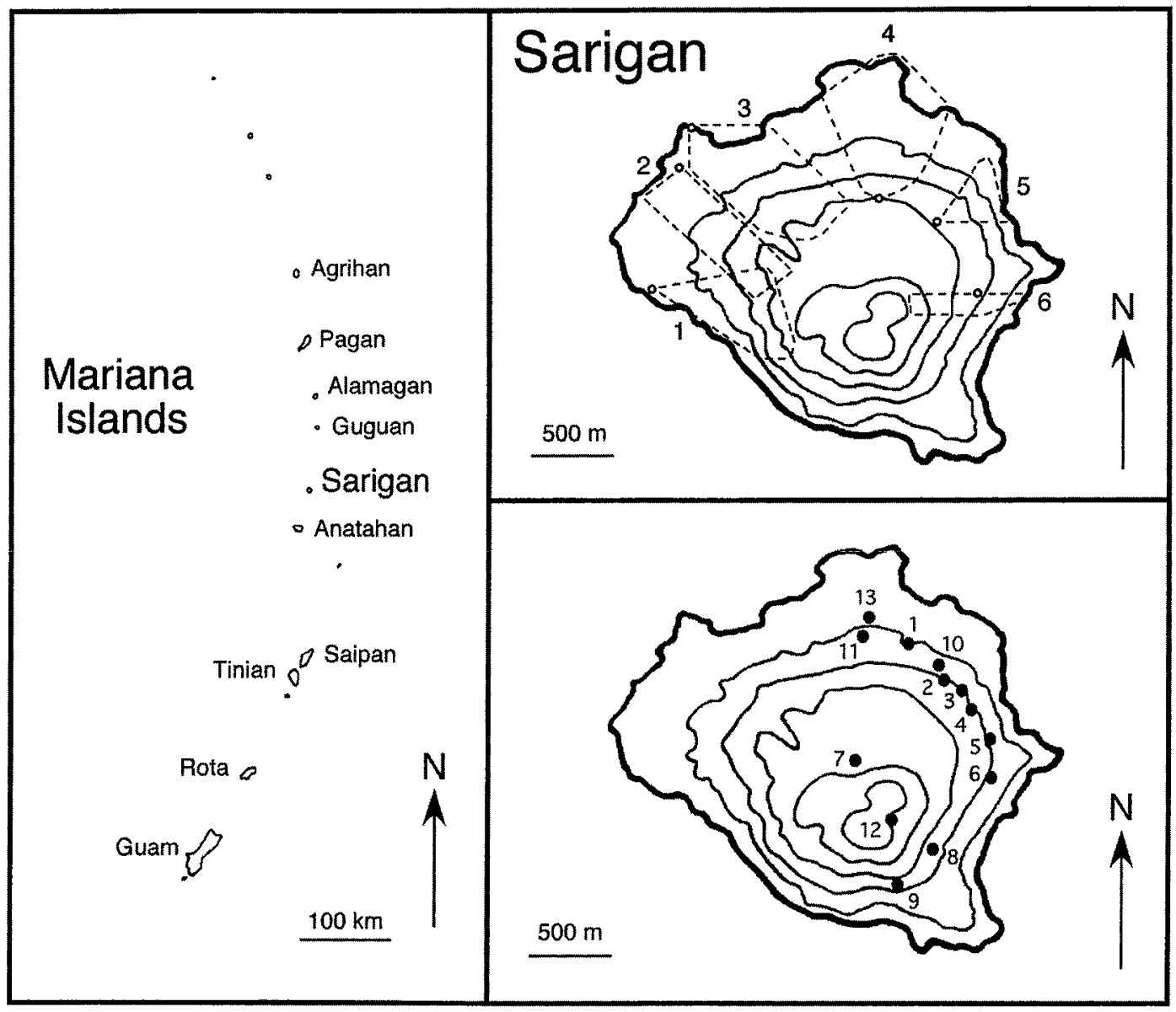

FIGURE 1. Maps of the Mariana Islands and Sarigan. Upper right inset shows the locations of six station counts (dashed lines) and observer positions (open circles) for Mariana fruit bats on Sarigan. Lower right inset shows the locations of 13 bat colonies and smaller aggregations (black circles), 1999-2001. Contour lines are displayed for 100-m intervals.

Population estimates of fruit bats were derived using a combination of several methods (Wiles 1987, Wiles et al. 1989, Worthington et al. 2001, Utzurrum et al. in press). Emphasis was placed on finding colonies and smaller aggregations (defined as containing 3-12 bats), where most bats were presumed to roost during the day. In 1999 and 2000, observers spent considerable effort hiking across the island in search of colonies, which were usually visible from vantage points overlooking sizable areas of forest or hillsides with scattered trees. We usually sat 10-200 m from roost trees and used spotting scopes or binoculars to count the number of visible bats present per location. At sites where all or nearly all bats could be viewed, final estimates of roost size were not expanded beyond the raw count tally or were increased by just a few additional animals to account for individuals that were likely present but hidden from sight by foliage. At a few sites where terrain or dense foliage made the viewing of bats in roost trees more problematic, final estimates of roost size were increased by up to $50 \%$ from raw count figures, depending on individual site conditions, to account for greater numbers of animals that were believed pres- 
ent. Infant bats were excluded from count tallies. The helicopter survey allowed much of the island to be searched for colonies during $45 \mathrm{~min}$ of flight time. The flight route consisted of one or two passes along the eastern and northern slopes of the island, with some additional circling to investigate and photograph one roost. Later examination of the photographs with a hand lens allowed the number of visible bats in this colony to be counted.

Abundance of solitary bats was assessed by recording the numbers of individuals or pairs seen roosting and flying as we hiked or scanned for colonies. We did not attempt to find solitary animals in 2001.

Evening station counts of flying fruit bats were made at four locations in 1999 and five locations in 2000 that offered broad views of the surrounding terrain (Figure 1). Unlike studies using this technique elsewhere in the Marianas (Wiles 1987, Stinson et al. 1992, Worthington et al. 2001), our station counts recorded both solitary and colonial animals as they flew about during the early evening. Counts provided data on the numbers of bats foraging and moving through each count area and were useful in searching for colonies by revealing locations where sizable numbers of bats emerged. Count data were used only as indices of abundance and were not directly employed in making population estimates. Counts began at 1730-1800 hours in 1999 and 1630-1700 hours in 2000, and lasted until darkness (about 1930 hours). Observers used binoculars and spotting scopes to view bats. Care was taken to avoid counting animals more than once; however, it is probable that some double counting occurred. The six count areas averaged ( \pm SE) $35.0 \pm 7.8$ ha (range, 12-52 ha).

Information on food habits was obtained by direct observations of feeding bats and from evidence found in the field, such as partially eaten fruit dropped beneath feeding sites, ejecta pellets, and fecal splats. During 1999, considerable time was spent making careful observations of colonial and solitary bats with spotting scopes or binoculars to record sex ratios, percentage of females with young, and other behavior. Sex ratio data from flying bats were not used because adult males with their highly visible genitalia were easier to identify and possibly more active than females or immature males.

We used a $t$-test to compare differences in colony size between habitat types.

\section{RESULTS}

\section{Abundance of Colonial Bats}

Survey teams achieved good coverage of the northern half of Sarigan in 1999 and 2000; however, the southern half of the island with its difficult terrain and dense fields of swordgrass was visited much less extensively. It is likely that no major colonies were overlooked during either trip and that most smaller groups of bats were eventually encountered.

In 1999, nine colonies or smaller aggregations of fruit bats were recorded, with a possible tenth colony also located (Table 1, Figure 1). All groups were small, numbering from three to an estimated 24 animals (Table 1). Only three roosts held more than 15 bats. Six sites were occupied at the end of the survey (Table 1) and held a combined estimate of 55-66 animals. An additional colony (roost 10) was suspected downslope from roost 2 on the final day but was not verified because of time constraints. Flying bats circled this site repeatedly during observations of roost 2 , indicating that a group of 10-20 animals perhaps was present. Based on counts at known roosts, plus the probable presence of a few additional undetected groups, we estimated that 75-100 fruit bats likely occurred in colonies or small aggregations on the island during this survey.

Three roosts containing a total of 90-100 bats were discovered in 2000, including one with 70-75 animals (Table 1). As in 1999, the survey probably missed a few smaller roosts; therefore we estimated the total number in this population segment at $110-135$ bats.

Two colonies were sighted from the helicopter in 2001. A substantial number of bats was observed flying over and roosting in nine or more trees spread over $120 \mathrm{~m}$ at roost 13 . Examination of photographs of the colony showed that 195 bats were present, but total 
TABLE 1

Estimated Numbers of Mariana Fruit Bats and Attributes of 12 Roosts and One Suspected Roost on Sarigan, Mariana Islands, 1999-2001

\begin{tabular}{|c|c|c|c|c|c|c|}
\hline $\begin{array}{l}\text { Roost } \\
\text { No. }\end{array}$ & Year & Habitat & $\begin{array}{l}\text { Approx. } \\
\text { Elevation } \\
\quad(\mathrm{m})\end{array}$ & $\begin{array}{l}\text { Species and } \\
\text { No. of } \\
\text { Roost Trees }\end{array}$ & $\begin{array}{l}\text { Maximum } \\
\text { No. of } \\
\text { Bats Counted }\end{array}$ & $\begin{array}{l}\text { Estimated } \\
\text { No. of } \\
\text { Bats Present }\end{array}$ \\
\hline $1^{a, b}$ & 1999 & Large stand of native forest & 100 & Unidentified (1) & 17 & $17-20$ \\
\hline 2 & 1999 & $\begin{array}{l}\text { Chrysopogon-covered ridge with } \\
\text { scattered coconut trees }\end{array}$ & 200 & Cocos nucifera (1) & 6 & $6-8$ \\
\hline $3^{b}$ & $\begin{array}{l}2000 \\
1999\end{array}$ & Cbrysopogon-covered ridge with & 200 & C. nucifera (1) & $\begin{array}{l}5 \\
7\end{array}$ & $\begin{array}{l}5 \\
7\end{array}$ \\
\hline $4^{b}$ & 1999 & $\begin{array}{l}1-2 \text { coconut trees } \\
\text { Chrysopogon-covered ridge with }\end{array}$ & 200 & C. mucifera (1) & 13 & 13 \\
\hline & & $\begin{array}{l}\text { Cbrysopogon-covered ridge with } \\
\text { scattered coconut trees }\end{array}$ & & & & \\
\hline 5 & 1999 & $\begin{array}{l}\text { Cbrysopogon-covered ridge with } \\
\text { scattered coconut trees }\end{array}$ & 175 & C. nucifera (2) & 20 & $20-24$ \\
\hline 6 & 1999 & $\begin{array}{l}\text { Chrysopogon-covered ridge with } \\
\text { scattered coconut trees }\end{array}$ & 175 & C. nucifera (2) & 3 & 3 \\
\hline 7 & 1999 & $\begin{array}{l}\text { Isolated stand of native forest } \\
\text { surrounded by Miscanthus }\end{array}$ & 350 & $\begin{array}{l}\text { Pandanus } \\
\text { tectorius (1) }\end{array}$ & 3 & 3 \\
\hline 8 & 1999 & $\begin{array}{l}\text { Cbrysopogon- and Nephrolepis- } \\
\text { covered slope with a few } \\
\text { native trees }\end{array}$ & 250 & Ficus prolixa (1) & 7 & $7-8$ \\
\hline 9 & 1999 & Ravine with strip of native forest & 250 & Not observed & 16 & $16-20$ \\
\hline $10^{c}$ & 1999 & Not observed & 170 & Not observed & - & $10-20$ \\
\hline 11 & 2000 & Large stand of native forest & 125 & $\begin{array}{l}\text { Ficus sp. (1), } \\
\text { unidentified (2) }\end{array}$ & 5 & $15-20$ \\
\hline 12 & 2000 & $\begin{array}{l}\text { Steep ravine with dense } \\
\text { Miscantbus and scattered } \\
\text { native trees }\end{array}$ & 500 & $\begin{array}{l}\text { F. prolixa (1), } \\
\text { Hibiscus tiliaceus } \\
(1)\end{array}$ & 63 & $70-75$ \\
\hline 13 & $\begin{array}{l}2001 \\
2001\end{array}$ & Large stand of native forest & 85 & $\begin{array}{l}\text { F. prolixa (1) } \\
\text { Unidentified ( } 9 \\
\text { or more) }\end{array}$ & $\begin{array}{r}32 \\
195\end{array}$ & $\begin{array}{c}40-48 \\
225-250\end{array}$ \\
\hline
\end{tabular}

"A colony of about 30-40 bats was seen in a Ficus prolixa tree near this location in January-February 1998 (C. Kessler and H. Gideon, pers, comm.).

${ }^{b}$ Roost was not occupied at the end of the 1999 survey.

${ }^{\epsilon}$ Roost was not observed but was suspected to occur because of the number of bats seen flying over the site (see text).

estimated colony size was expanded to $225-$ 250 bats to account for animals concealed by leaves. Roost 12 was censused from the ground, with 32 bats viewed. However, part of the roost tree was hidden below a cliff; thus total numbers were increased to $40-48$ bats. Because of the shorter length of this survey and that helicopter surveys are not sensitive to locating smaller colonies, it is likely that some small roosts were overlooked during this survey.

\section{Abundance of Nonaggregating Bats}

Solitary roosting and flying fruit bats were regularly encountered in all habitats with trees throughout Sarigan in 1999 and 2000, except at the southern end of the island where adequate observations were not made. Pairs of animals were also seen occasionally. Solitary bats were fairly active throughout the day, with flying individuals commonly recorded at all hours, including midday. Many animals frequently changed roosting sites, although some of this activity was probably due to observer presence or disturbance by other team members working on the island.

Total numbers of nonaggregating bats were difficult to quantify for a variety of reasons, including poor visibility in closedcanopy forests and the high mobility of some individuals. However, based on general num- 
TABLE 2

Comparison of Evening Station Count Results for Mariana Fruit Bats in 1999 and 2000 on Sarigan, Mariana Islands

\begin{tabular}{ccccc}
\hline Year & $\begin{array}{c}\text { No. of } \\
\text { Stations }\end{array}$ & $\begin{array}{c}\text { Total Area } \\
\text { Surveyed (ha) }\end{array}$ & $\begin{array}{c}\text { Total No. } \\
\text { of Bats }\end{array}$ & $\begin{array}{c}\text { Mean No. } \\
\text { of Bats/ha }\end{array}$ \\
\hline 1999 & 4 & 146.2 & 104 & 0.71 \\
2000 & 5 & 179.8 & 150 & 0.83 \\
\hline
\end{tabular}

${ }^{a}$ Counts were made at the following station numbers: $1999: 1,3,4$, and $6 ; 2000: 2,3,4,5$, and 6 .

bers seen during daytime observations and evening station counts in 1999 and 2000, a rough islandwide estimate of $75-100$ bats was reasonable for both years. Abundance of solitary individuals was not assessed in 2001, but we presumed that at least some animals were present, as in both previous years.

\section{Total Population Estimates}

Using the figures presented in the previous section, we estimated the total fruit bat population on Sarigan to number 150-200 bats in 1999 and $185-235$ bats in 2000. Population size was difficult to determine for 2001. Based on numbers at the two colonies, plus additional animals presumed to occur in smaller groups or solitarily, we estimated that about 300-400 bats were present.

\section{Station Count Results}

Only a few evening station counts were conducted in 1999 and 2000; however, their results suggest that similar numbers of bats were present on the island in both years (Table 2).

\section{Habitat Use and Roosting Bebavior}

All fruit bat roosts occurred in the eastern half of Sarigan in three habitat types (Figure 1, Table 1). Five aggregations resided in single or clumps of several coconut trees sparsely distributed on steep hillsides with short Cbrysopogon grasslands. Small isolated patches of native forest held four roosts, and more extensive stands of native forest contained three others. No groups of bats were located in the closed-canopy coconut forest on the northwest side of the island. Trees used at different roosts included Cocos nucifera $(n=7)$, Ficus prolixa (2), Ficus sp. (1), Hibiscus tiliaceus (1), Pandanus tectorius Sol. ex Park. (1), and unidentified (12) (Table 1). Previous observers have also noted the use of large $\mathrm{Fi}$ cus by colonies on Sarigan (Wiles et al. 1989; C. Kessler, pers. comm.). Most of the unidentified trees had been defoliated by the bats, making identification impossible from distant viewing points. Average roost size was larger in native forest (average $=53.9$ bats) than in coconut trees (average $=9.5$ bats), but the difference was not significant $(t=1.303, \mathrm{df}=12, P=0.217)$. Elevations of roosts ranged from 85 to $500 \mathrm{~m}$ (Table 1).

Bat aggregations appeared to be relatively mobile, with only two sites occupied in multiple years (Table 1). Three roosts were abandoned during the surveys, including two (roosts 3 and 4) that were unintentionally flushed by observers. Roost 1 was not disturbed but was present for only 1-2 days. Most of the bats in these groups presumably joined other aggregations by the end of the 1999 survey.

Limited observations of groups in 1999 revealed that most were probably composed of harems. This conclusion was based on the identification of multiple females (about 5 to 15 ) per male at roosts 3,4 , and 5 . One male was seen interacting with a female and climbing among roosting perches in a manner resembling harem male behavior on Guam (G.J.W., unpubl. data). Fancy et al. (1999) reported an all-male aggregation of 15 bats in 1997.

In 1999, the abundance of solitary bats appeared greatest in native forest on the northeastern side of the island and in scat- 
tered coconut trees on grassy hillsides along the eastern coast. Both habitats offered either numerous viewpoints or sparse tree cover, making it easy to sight bats. Solitary animals were encountered less often in coconut forest, but detectability was reduced in that plant community because of denser vegetation and fewer viewing points. Individuals used a variety of native tree species and coconut trees as roosts.

A sex ratio of 8 females: 10 males $(55.6 \%$ male) was noted among 18 bats seen roosting alone in 1999. Courtship behavior was observed once between a noncolonial male and female with a medium-sized juvenile. The male flew in and landed near a female roosting in a coconut tree, courted her unsuccessfully for about $2.5 \mathrm{~min}$, and then flew off.

In 1999, a large number of roosting bats were observed being harassed and presumably bitten by small flying insects, which were subsequently identified as possibly a type of biting midge (R. Muniappan, pers. comm.). The bats, which hung with their wings wrapped around themselves, were initially noted making repeated rapid, shallow flicks of their outer wing. Closer inspection of one animal from $6 \mathrm{~m}$ away revealed at least $10-15$ insects swarming around its body and that its wing flicking and other body-shaking movements were in response to their irritation. The bat performed a mean of 22.1 wing flicks, 1.3 head-neck shakes, 0.3 body adjustments, and 0.2 leg shakes per minute $(n=10 \mathrm{~min})$. A second individual at another location averaged 15.0 wing flicks and 1.0 head-neck shake per minute $(n=5 \mathrm{~min})$. The irritation appeared great enough to prevent the bats from settling into a deep sleep. Bats exhibited wing flicking in all habitats, although several colonies on the eastern and more windswept grassy ridges did not seem bothered.

\section{Reproduction}

In 1999, females with young were observed commonly throughout the survey while roosting and flying. Twenty-eight of 50 $(56 \%)$ females recorded in colonies or small aggregations (roosts 2, 3, 4, 5, 8, and 9) possessed young. In addition, three of eight
$(37.5 \%)$ solitary females carried infants. However, our data for animals roosting in groups are probably biased toward a higher percentage of females with young than in fact was present. Sufficient time was not available to identify all individuals in each group, which is the most desirable method for obtaining true female-young ratios. During incomplete observations, females with juveniles are sometimes more easily recognized because the young often form a noticeable bulge under their mother's wing, they receive additional grooming from the mother, and the extra activity of the young often helps the observer note their presence. Females without young are commonly less active while roosting and therefore require more time to identify. Based on these considerations, probably $30-50 \%$ of the females on the island possessed young during the 1999 survey. Eleven juveniles were classified by size, as follows: one small, nine medium-sized, and one large.

\section{Diet}

We obtained 23 feeding records during 1999 and 2000, which included the following foods: the fruits of Terminalia catappa L. $(n=11)$, Neisosperma oppositfolia (3), Pandanus tectorius (3), Ficus tinctoria (1), and Ficus sp. (1); the flowers of Cocos nucifera (3); and sap from the flower stalks of $C$. nucifera (1). Terminalia catappa and $P$. tectorius are both uncommon on Sarigan, yet their fruits were heavily fed on in many instances. Despite deliberate searching in 1999 , no evidence of feeding was located under numerous large Ficus trees with ripening fruit. Of the many late afternoon and evening sightings of flying bats in 1999, only one animal was seen carrying a fruit in its mouth, indicating that most feeding occurred in or near the crowns of fruiting trees. We also commonly found uneaten fruits from a variety of species on the ground under parent trees that year.

On one evening at 1930 hours, four fruit bats were seen clustered around the crown of a coconut tree, where a set of older flower stalks protruded upward. Although the stalks no longer possessed flowers, the bats' activity 
TABLE 3

Population Estimates of Mariana Fruit Bats and Methods Used to Derive Estimates on Sarigan, Mariana Islands, $1983-2001^{a}$

\begin{tabular}{|c|c|c|c|}
\hline Date & Population Estimate & Methods & Source \\
\hline September 1983 & Minimum of 125 & Station counts & Wiles et al. (1989) \\
\hline March 1997 & $\begin{array}{c}170(95 \% \text { confidence } \\
\text { interval, 101-238) }\end{array}$ & Variable circular plots & Fancy et al. (1999) \\
\hline July 1999 & $150-200$ & $\begin{array}{l}\text { Colony counts, ground searches } \\
\text { for solitary bats, station counts }\end{array}$ & This study \\
\hline July 2000 & $185-235$ & $\begin{array}{l}\text { Colony counts, ground searches } \\
\text { for solitary bats, station counts }\end{array}$ & This study \\
\hline July 2001 & About $300-400$ & Colony counts, helicopter searches & This study \\
\hline
\end{tabular}

a Although structured counts of fruit bats were not made during 2 months of ungulate control work in January-February 1998 , bat numbers were consistent with those observed in 1999 and 2000 , including a lack of colonies with more than 40 bats (Zoology Unlimited LLC 1998; C. Kessler, pers. comm.).

indicated that the stalks were exuding sap from multiple openings. A dominant bat occupied the stalks, and the other animals hung $50-100 \mathrm{~cm}$ away on separate fronds watching the dominant individual feed. The bat nearest the center tried several times to approach the crown and insert its head among the stalks but was rebuffed each time by brief snarls from the dominant animal. The two outermost bats departed after 9-12 min and were followed soon after by the dominant individual. The remaining bat immediately moved to the crown and began clambering about to lick different parts of the stalks. It frequently changed positions and returned to relick locations that had already been visited. The number of animals involved and the resource defense displayed by the one individual suggest that coconut sap is a desirable food. Consumption of coconut sap by $P$. mariannus has been reported previously in the Caroline Islands (Wiles et al. 1991).

Other feeding records of fruit bats from Sarigan include frequent visitation of Erythrina variegata flowers in March 1997 (N.C.J., pers. obs.) and January and February 1998 and 2002 (C. Kessler and L. Williams, pers. comm.). This tree flowers seasonally from December through April. In September 1983, observers noted heavy use of coconut flowers (T. Lemke and N. Payne, pers. comm.) and several instances of eating the fruit of $P$. tectorius and $N$. oppositifolia (G.J.W., pers. obs).

\section{DISCUSSION}

Repetitive census data are essential to understanding the population dynamics of wildlife and implementing appropriate management practices. Such information currently is available for only a few Pteropus populations in Oceania, primarily those in the southern Mariana Islands and American Samoa (Utzurrum et al. in press). Multiple population estimates of fruit bats are now available for Sarigan from 1983 to 2001 and indicate that a relatively stable population of about $125-235$ animals was present until 2000 (Table 3). This corresponds to densities of $0.77-1.45$ bats per hectare of forest or $0.25-0.47$ bats per hectare of total land area. In contrast to substantial population declines in recent years on the larger neighboring islands of Anatahan and Pagan (Johnson 2001, Worthington et al. 2001), Sarigan shows no evidence of decreasing bat abundance over time. Overhunting is a major cause of Pteropus declines in the Marianas and elsewhere (Falanruw 1988, Wiles et al. 1989, Fujita and Tuttle 1991, Pierson and Rainey 1992, Stinson et al. 1992, Craig et al. 1994, Brooke and Tschapka 2002). Although illegal hunting occurs on Sarigan (Zoology Unlimited LLC 1998), its extent seems surprisingly limited given the proximity of the island to Saipan (155 km away), which is the most populous island in the CNMI. We noted little evidence of poaching 
during our surveys, finding fewer than five expended shotgun shells of the appropriate size for bats in 1999. Furthermore, bats frequently allowed us to approach within 6-8 m during observations, another indication that they were not heavily persecuted.

Without the extensive hunting typical of many other Mariana Islands (Stinson et al. 1992, Krueger and O'Daniel 1999, Worthington et al. 2001), Sarigan is the first island studied in the archipelago where fruit bat abundance still appears to be largely restricted by natural processes. Because of the island's small size and limited forest cover, we speculate that food availability is the primary factor preventing population growth beyond about 200 bats under most conditions. The large amount of uneaten fallen fruit from a variety of species in 1999 suggests that an inadequate food supply occurs seasonally rather than year-round. Due to its abundance, coconut is probably the most important dietary component of Sarigan's bats. Coconut flowering occurs year-round in Micronesia; however, there may be periods when flower abundance is reduced enough to affect fruit bat survival. Native forest occupies just 29 ha of the island and is characterized by low tree species diversity. Both attributes increase the likelihood of seasonal periods of lowered fruit production, which may also influence the island's carrying capacity for bats.

Sarigan's larger fruit bat population in 2001 , which expanded by perhaps $28-116 \%$ in one year, increased too rapidly to be caused solely by natural recruitment and was more likely due to the immigration of up to several hundred animals from another island. The presence of an unusually large colony supports this belief and further suggests that the movement occurred as a single event. Although there are several previous records of individual bats apparently flying from Guguan to Sarigan (Wiles et al. 1989), we believe that Anatahan is the most likely source of the new animals for several reasons. It supports a sizable bat population (currently 1,000 or more bats [Johnson 2001]), is the closest island to Sarigan (37 km away), and is thought to be regularly visited by hunters (Worthington et al. 2001). Guguan and Ala- magan, the nearest islands to the north (66 $\mathrm{km}$ and $94 \mathrm{~km}$ away, respectively), harbor smaller source populations of at least 100550 bats (Johnson 2001). Hunting pressure on Guguan is probably no greater than on Sarigan.

Many continental populations of Pteropus make annual large-scale movements in response to shifting food resources (Marshall 1983, Richards 1995, Vardon et al. 2001), but similar types of movement have not yet been demonstrated for insular populations. In the southern Marianas, colony-sized movements between islands are known to occur rarely but are usually associated with hunting or other human disturbance at roosts (Wiles and Glass 1990). There is also evidence that some bats travel seasonally between Guam and Rota (G.J.W., unpubl. data). Fruit bat movements in the northern Marianas are virtually undocumented (Wiles et al. 1989, Wiles and Glass 1990). Our study provides the first evidence that sizable movements also occur among these islands; although based on census data from Sarigan, these do not appear to be regular. Human disturbance is probably involved in some of these events, but food scarcity may be another stimulus, particularly after severe typhoons have temporarily reduced the availability of fruits and flowers on an island. Intense storms strike individual islands in the Marianas at least once a decade on average. However, during the year before July 2001, only one relatively mild tropical storm affected the islands from Anatahan to Pagan. It passed over Anatahan on 7 September 2000 with maximum sustained winds of $100 \mathrm{~km} / \mathrm{hr}$, causing only minor vegetative damage that presumably did not induce notable emigration by bats.

The limited data gathered thus far from the northern Marianas indicate that fruit bat populations are largely sedentary. An absence of reports by local islanders of sizable interisland movements by bats supports this belief. We surmise that several factors have prevented annual migrations from evolving in the northern islands. Probably of greatest importance is the overall lack of spatial and temporal variation in the dietary resources of bats because of the similarity of the forests on 
these islands (Ohba 1994). Regular movements are perhaps also discouraged by the small $\left(<7.5 \mathrm{~km}^{2}\right)$ sizes of four of the eight islands, which presumably lack sufficient food to support large numbers of transient animals for more than a short time. Finally, fruit and flower resources may be unreliable because of occasional typhoon damage to forests. Elsewhere in its range, $P$. mariannus is reported by some islanders in the Palau Islands to make limited seasonal movements in response to changing availability of preferred foods (Wiles et al. 1997), but this remains unverified.

The social behavior of Pteropus varies considerably among species, ranging from some that are highly colonial to others that are primarily solitary (Pierson and Rainey 1992). The extent of coloniality can also vary within a species. Although $P$. mariannus is gregarious throughout its range, average colony size is considerably greater in some locations (e.g., some islands in the Marianas [Wiles 1987, Wiles et al. 1989, Stinson et al. 1992, Worthington et al. 2001]) than others (e.g., Palau, Yap, and Ulithi [Engbring 1985, Wiles et al. 1991, 1997]). Most studies in the Marianas have reported that populations are predominately colonial, with most individuals roosting in groups of a few to as many as 2,000 bats. Larger islands with relatively large bat populations (i.e., Guam, Rota, Anatahan, and Pagan) are especially likely to have colonies exceeding several hundred animals. Our study on Sarigan is the first to examine roosting behavior in a small population on one of the archipelago's smallest islands. Results of our study combined with the observations of previous authors (Wiles et al. 1989, Zoology Unlimited LLC 1998, Fancy et al. 1999) show that Sarigan's population usually features smaller roost sizes of $3-75$ bats. Numerous solitary animals are also present and at times comprise up to half of the population. Our study is also one of the first to describe the solitary component for any primarily colonial Pteropus population. An almost equal sex ratio occurred among these bats. Some lone females with young were also noted.

Fruit bat colonies roosted in several habitats on Sarigan but avoided dense coconut forest with a closed canopy. Preferred roosting trees included isolated $C$. nucifera and emergent Ficus. These trees are probably selected over sites in coconut forest because they offer clearer access to and from roosting branches (Pierson and Rainey 1992). We cannot rule out that insect harassment may have been partially responsible for the roosting patterns and site selection of the bats seen in 1999. The bats may have been trying to avoid the insects by choosing the more open and breezy conditions associated with scattered coconut trees on the northeastern side of the island. The insects may also have been responsible for the frequent movement between roost trees seen in some solitary bats.

Because fruit bat abundance on Sarigan appears to be restricted by limited habitat availability, we recommend that plantings of native trees be made to increase the amount of forest on the island and to enhance its value for bats. Such a program will benefit other native wildlife and is likely to succeed now that ungulates have been eradicated. We encourage the use of trees indigenous to the northern islands to maintain the natural species composition of the forest.

\section{ACKNOWLEDGMENTS}

We thank the following people for their assistance during the surveys: J. Morton, J. de Cruz, T. Sutterfield, C. Kessler, H. Gideon, L. Williams, M. Lusk, R. Lazaro, S. Vogt, L. Gibson, L. Rangamar, M. Severson, and V. Sutterfield. M. Cunningham piloted the helicopter in 2001.

\section{Literature Cited}

Brooke, A. P., and M. Tschapka. 2002. Threats from overhunting to the flying fox, Pteropus tonganus (Chiroptera: Pteropodidae) on Niue Island, South Pacific Ocean. Biol. Conserv. 103:343-348.

Craig, P., P. Trail, and T. E. Morrell. 1994. The decline of fruit bats in American Samoa due to hurricanes and overhunting. Biol. Conserv. 69:261-266.

de Cruz, J., L. Arriola, N. Johnson, and G. Beauprez. 2000. Wildlife and vegetation 
surveys, Sarigan, 2000. Technical Report 5, Division of Fish and Wildlife, Saipan, Commonwealth of the Northern Mariana Islands.

Engbring, J. 1985. A 1984 survey of the fruit bat (magalau) on Yap. U.S. Fish and Wildlife Service, Honolulu, Hawai'i.

Falanruw, M. V. C. 1988. On the status, reproductive biology, and management of fruit bats of Yap. Micronesica 21:39-51.

Fancy, S. G., R. J. Craig, and C. Kessler. 1999. Forest bird and fruit bat populations on Sarigan, Mariana Islands. Micronesica 31:247-254.

Farrell, D. A. 1991. History of the Northern Mariana Islands. Public School System, Saipan, Commonwealth of the Northern Mariana Islands.

Fujita, M. S., and M. D. Tuttle. 1991. Flying foxes (Chiroptera: Pteropodidae): Threatened animals of key ecological and economic importance. Conserv. Biol. 5:455463.

Johnson, N. C. 2001. A survey of Mariana fruit bats in the Mariana Islands, including recent minimum population estimates, July 2001. Pages 49-90 in Annual report FY 2001, Division of Fish and Wildlife, Saipan, Commonwealth of the Northern Mariana Islands.

Krueger, S., and D. O'Daniel. 1999. Observations of Mariana fruit bats on Tinian. Micronesica 31:367-371.

Marshall, A. G. 1983. Bats, flowers and fruit: Evolutionary relationships in the Old World. Biol. J. Linn. Soc. 20:115-135.

Ohba, T. 1994. Flora and vegetation of the northern Mariana Islands, Micronesia. Pages 13-69 in A. Asakura and T. Furuki, eds. Biological expedition to the northern Mariana Islands, Micronesia. Natural History Research, Special Issue No. 1. Natural History Museum and Institute, Chiba, Japan.

Pierson, E. D., and W. E. Rainey. 1992. The biology of flying foxes of the genus Pteropus: A review. Pages 1-17 in D. E. Wilson and G. L. Graham, eds. Pacific island flying foxes: Proceedings of an international conservation conference. U.S. Fish Wildl. Serv. Biol. Rep. 90 (23).
Richards, G. C. 1995. A review of ecological interactions of fruit bats in Australian ecosystems. Symp. Zool. Soc. Lond. 67:7996.

Stinson, D. W., P. O. Glass, and E. M. Taisacan. 1992. Declines and trade in fruit bats on Saipan, Tinian, Aguijan, and Rota. Pages 61-67 in D. E. Wilson and G. L. Graham, eds. Pacific island flying foxes: Proceedings of an international conservation conference. U.S. Fish Wildl. Serv. Biol. Rep. 90 (23).

Utzurrum, R. C. B., G. J. Wiles, A. P. Brooke, and D. J. Worthington. in press. Count methods and population trends in Pacific island flying foxes. Pages 49-62 in T. J. O'Shea and M. A. Bogan, eds. Monitoring trends in bat populations of the United States and Territories: Problems and prospects. U.S. Dep. Inter. U.S. Geol. Surv. Inf. Technol. Rep. 2003-0003.

Vardon, M. J., P. S. Brocklehurst, J. C. Z. Woinarski, R. B. Cunningham, C. F. Donnelly, and C. R. Tidemann. 2001. Seasonal habitat use by flying foxes, Pteropus alecto and $P$. scapulatus (Megachiroptera), in monsoonal Australia. J. Zool. (Lond.) 253:523-535.

Wheeler, M. E. 1980. The status of the Marianas fruit bat on Saipan, Tinian, and Rota. 'Elepaio 40:109-113.

Wiles, G. J. 1987. The status of fruit bats on Guam. Pac. Sci. 41:148-157.

Wiles, G. J., and P. O. Glass. 1990. Interisland movements of fruit bats (Pteropus mariannus) in the Mariana Islands. Atoll Res. Bull. 343:1-6.

Wiles, G. J., T. O. Lemke, and N. H. Payne. 1989. Population estimates of fruit bats (Pteropus mariannus) in the Mariana Islands. Conserv. Biol. 3:66-76.

Wiles, G. J., J. Engbring, and M. V. C. Falanruw. 1991. Population status and natural history of Pteropus mariannus on Ulithi Atoll, Caroline Islands. Pac. Sci. 45:7684.

Wiles, G. J., C. F. Aguon, G. W. Davis, and D. J. Grout. 1995. The status and distribution of endangered animals and plants in northern Guam. Micronesica 28:31-49.

Wiles, G. J., J. Engbring, and D. Otobed. 
1997. Abundance, biology, and human exploitation of bats in the Palau Islands. J. Zool. (Lond.) 241:203-227.

Worthington, D. J., A. P. Marshall, G. J. Wiles, and C. C. Kessler. 2001. Abundance and management of Mariana fruit bats and feral ungulates on Anatahan, Mar- iana Islands. Pac. Conserv. Biol. 7:134142.

Zoology Unlimited LLC. 1998. Report on the eradication of feral ungulates from Sarigan Island, Commonwealth of the Northern Mariana Islands, USA. Zoology Unlimited LLC, Flagstaff, Arizona. 